\title{
Forensic Accounting in Malaysia: Some Insights from Practitioners
}

\author{
Mohd Sarif Ibrahim and Mazni Abdullah ${ }^{1}$
}

\begin{abstract}
This study aims to provide an overview of forensic accounting in Malaysia. Semi-structured interviews were used in which practitioners were asked regarding the development and future prospects of forensic accounting in Malaysia. The findings show that despite the importance of forensic accounting in today's business, its development in Malaysia is slow and still in its infancy stage. Nevertheless, the practitioners are of a view that the career of forensic accounting has good future prospects in Malaysia.
\end{abstract}

Keywords: Forensic Accounting, Practitioners, Malaysia

\section{Introduction}

Corporate financial scandals, such as the often cited Enron and WorldCom cases of the last few years, are a wake-up call to the accounting profession and have rejuvenated the interest in forensic accounting. Increasing government regulations and pressure from other stakeholders has made businesses acutely aware of the consequences of employees' misdeeds and inadequate internal controls. Companies are now beginning to be more determined than ever to ensure that their operations are above board and in no way connected with illegal activities. This has resulted in a steadily growing demand for professionals trained in the art of detecting, correcting and preventing fraud as well as deceptive accounting practices.

In the US, the considerable growth in forensic accounting careers can be seen through the many universities offering forensic accounting related courses. Also, many professional organisations and associations are promoting fraud examination and forensic accounting. Further, three of the top six accounting niche services fall within the forensic accounting area: business valuations, litigation support and forensic/fraud (Covaleski, 2003). However, in Malaysia, so far, only one institution of higher learning in Malaysia offers a forensic accounting course at the postgraduate level. Universiti Teknologi Mara (UiTM) offers the

Corresponding author: Dr Mazni Abdullah is a Senior Lecturer in the Faculty of Business and Accountancy, University of Malaya; email: mazni@um.edu.my. Encik Mohd Sarif Ibrahim was a Senior Lecturer in the Faculty of Business and Accountancy, University of Malaya. 
Master in Forensic Accounting and Financial Criminology. The programme was embarked upon in collaboration with the Anti-Corruption Agency of Malaysia (ACA) as an effort to develop expertise in forensic accounting in Malaysia. Other universities either introduce the forensic accounting subject as an elective course or incorporate it as part of the syllabus in the accounting or auditing course. The professional bodies in Malaysia have yet to introduce a paper in forensic accounting. Forensic accounting practitioners normally become Certified Fraud Examiners, an accreditation given by the Association of Certified Fraud Examiners in the United States. To the knowledge of the authors, so far, information about forensic accounting in Malaysia is limited or almost non-existent in the academic literature. This study therefore attempts to provide some overview about the development and future prospect of forensic accounting in Malaysia, and, consequently, contribute to the forensic accounting literature.

The remainder of this paper is structured as follows. The next section provides a review of the literature on forensic accounting. The third section discusses the research methodology in the study. The fourth section presents the findings, followed by the conclusion in the fifth section.

\section{Literature Review}

Forensic accounting is not a new field, as evidence shows that the profession has been in existence a long time albeit the profession was not always called forensic accounting. In ancient Egypt, forensic accountants, who inventoried the Pharaohs' grain, gold and other assets, were called the 'eyes and ears' of the Pharaohs. Other evidence of the existence of forensic accounting can be traced back to 1817 when an accountant who examined the account of a bankrupt was required to testify in a court case (Crumbly, 2001). Some sources traced the practice's origin as far back as nineteenth-century Scotland when a young Scottish accountant issued a circular advertising his expertise in arbitration support in 1824. In the late 1800s and 1900s, articles began to appear discussing expert witnessing, evidence arbitration and awards. It has been said that the phrase 'forensic accounting' was first used by Maurice E. Peloubet, a partner in a New York accounting firm, in his article in 1946.

To date, various definitions have been given to describe forensic accounting. According to Thornhill (1995), there has been no formal definition of forensic accounting. Webster's Dictionary defines forensic as "pertaining to, connected with, or used in the courts of law or public discussion and debate". According to Taylor (2011, p. 1), the word forensic comes from the Latin 'forensis', which carries the meaning of "gathering the facts to support an argument, providing facts or evidence in a court of law". Bolgna and Lindquist (1987) described forensic accounting as the application of financial skills and mental investigation of unresolved issues conducted within the context of the rules of evidence. Forensic accountants are also viewed as qualified and experienced individuals, familiar 
with criminal and civil law, and mostly working in professional accounting firms (Digabriele, 2008; Taylor, 2011).

It is also important to highlight that forensic accountants and auditors differ in their roles, knowledge and skills (Gray, 2008). According to Gray (2008, p. 115), "forensic accountants are viewed as a combination of an auditor and private investigator". Essentially, the tasks of forensic accountants are broader than auditors. While investigation of forensic accountants include identification of fraud, the auditors are not responsible for identifying fraud. The auditors' main responsibility is to offer opinion on a company's financial statements whereas forensic accountants are engaged to determine whether there has been any intentional misrepresentation associated with a company's financial statements. Therefore apart from investigative skills and business acumen, forensic accountants also need analytical abilities that include quantitative methods, an ingenious mindset, strong written and communication skills, the ability to comprehend the internal control systems and to assess the risks of corporations, and law enforcement officer insights (Gray, 2008; Ramaswamy, 2005; Messmer, 2004). Additionally, the knowledge of psychology is another value added for forensic accountants that will help them to understand the whim behind criminal deeds that motivate and encourage financial deception (Digabriele, 2008; Gray, 2008).

\section{Research Methodology}

Interviews are the best approach to acquire information that is not documented or not available in public. This study uses a semi-structured interview because it gives the interviewer sufficient flexibility to adapt questions in response to different circumstances and perspectives. Accounting practitioners from the big accounting firms, professional bodies and regulatory bodies in Malaysia were approached to be interviewed either in person or over the phone. Finally, 12 respondents agreed to be interviewed for this study, consisting of directors and senior managers from the big and medium accounting firms and senior executives from Bursa Malaysia, the Securities Commission, Malaysian Institute of Accountants and professional accounting bodies, namely, the Association of Chartered Certified Accountants (ACCA) and the Malaysian Institute of Certified Public Accountants (MICPA). The interviews were conducted in person by the same interviewer between February 2007 and March 2007. The interviews lasted between 30 to 90 minutes. Each interview was recorded and subsequently transcribed for review. The respondents were assured that their names would be kept anonymous and that their answers were their own personal views or opinions and not representative of their organisation. The respondents' views regarding the development and future prospect of forensic accounting in Malaysia were sought during the interviews. Basically, the respondents were asked the following questions. 
1. How do you perceive the development of forensic accounting in Malaysia?

2. In your opinion, what are the skills needed or minimum requirements to be a forensic accountant?

3. What do you think of the future prospect of forensic accounting in Malaysia?

\section{Findings}

The findings from the interviews are presented under the following headings: the development of forensic accounting in Malaysia, skills and minimum requirements needed by forensic accountants and future prospects of forensic accounting in Malaysia.

\subsection{The Development of Forensic Accounting in Malaysia}

It was found that all respondents were of the opinion that forensic accounting in Malaysia is still in its infancy stage compared to developed countries. According to one of the respondents, there appear to be some misconceptions of forensic accounting among Malaysians that need to be clarified. Most of them assumed that forensic accounting and auditing are the same whereas these two accounting disciplines are different in terms of their objectives and requirements. Auditing is the persistent process engaged by the company to give an opinion on the true and fair view of the financial statements, whereas forensic accounting concerns detecting any fraud or irregularity that happens in the company and is carried out on demand by the company. According to the respondents, there are several factors that may affect the current level of forensic accounting development in Malaysia.

First, forensic accounting is seen as an expensive service that only big companies can afford to detect any irregularities or fraud in their companies. In addition, it is quite costly if the issues are brought to court and where it involves a forensic accountant as an expert witness. Thus, most companies prefer to settle the issue outside the court to avoid the expensive cost and the risk of bad publicity to their corporate image. Second, there is no mandatory requirement set by the regulatory authorities on the companies to conduct forensic accounting, even for companies in financial distress. To date, there is no specific Act or guideline on forensic accounting practices in Malaysia. On this matter, some of the respondents suggested that Malaysia should have a specific Act to govern forensic accountants. They believe that such an Act will not only govern forensic accountants but also create awareness among the victims and society as a whole. Third, money laundering activities are not significant in Malaysia as, to date, the cases detected are few. The respondents believe that the current system used by the Central Bank is considered complete and able to detect any money laundering transactions. Fourth, is the lack of whistleblower protection in Malaysia; the role of the whistleblower is important to divulge corruption in the organisation. 
Forensic accountants also need cooperation from whistleblowers to clarify certain issues. One of the respondents commented that:

"... the fact is that only a few people will blow the whistle if they believe that by doing so it will put them in a spot. I think that the lack of whistleblower protection might be a factor that dissuades people from coming forward to highlight illegal or unethical acts within their organisations." [Senior Executive 3]

Even though efforts have been taken by the Securities Commission (SC) and Central Bank of Malaysia to encourage internal and external whistleblowers to disclose wrongdoings, most of the respondents opined that, as yet, no laws have been enacted to protect whistleblowers against retaliation. They believe that new legislation will help to create open working environments where individuals can raise concerns without fear of recrimination.

\subsection{Skills and Minimum Requirements Needed by Forensic Accountants}

In respect of the skills needed by forensic accountants, all the respondents are of the same opinion that working experience is a crucial factor in determining whether a person can become a forensic accountant in Malaysia. In terms of the number of years of working experience needed to be a good forensic accountant, most of the respondents view that a minimum working experience of 3 years is required. However, all the respondents agreed that fresh graduates are not suitable to be recruited as forensic accountants. Since a forensic accounting team may consist of lawyers, accountants, computer forensic experts and law enforcers like the police and customs officers, the name 'forensic accountant' is not restricted to a person who holds an accounting degree. Even so, it is advisable to have experience in external audit and internal audit before one becomes a forensic accountant. According to Grippe and Ibex (2003), the most important skills of forensic accountants, not only come from experience in accounting, auditing, taxation and business operations and management, but also from interpersonal relationships and communication.

The respondents also believe that one should have some basic knowledge of psychology to assist in interrogation of the suspect or witness process. While to be a computer forensic expert, one should have a strong information technology background, particularly when rapid technological changes are common in today's business environment. Besides these criteria, other skills that seem important to be a forensic accountant include the knowledge of relevant laws and legal system, communication and interpersonal skills to deal with clients, analytical skills and critical mind, logic and common sense relating to criminal behaviour, and interviewing and interrogation skills in identifying potential suspects. 


\subsection{Future Prospects of Forensic Accounting in Malaysia}

All the respondents claimed that there are good prospects for the career of forensic accounting in Malaysia. Globalisation, increase of foreign direct investment (FDI) and rapid development in technology are among the factors cited by respondents that will contribute to the demand for forensic accountants. Businesses have become more complex and thus any irregularities or fraud in the transactions are hard to detect by ordinary staff, even the auditing processes either, external or internal, are insufficient. As one of the respondents argued:

"One should understand that the audit is based on the samples selected and the responsibility of auditor is only to express the true and fair view of financial statements. A high level of expertise is needed to analyse complicated financial transactions and to identify any fraud ...the auditors cannot do this (job), so there is a demand of forensic accountants here. In our business today, we need both auditors and forensic accountants to crusade against financial deceptions. It is important in today's business environment to issue a transparent financial report in order to convince and regain the trust of investors." [Audit Manager 7]

Thus, forensic accounting is seen as an essential tool to offer the highest level of assurance and to add credibility to the financial statements in today's business environment. The demand for forensic accountants is also increasing, as Andrew Bernstein, the director of forensic and valuation services with Miami-based Berkowitz Dick Pollack \& Brant, comments, "Fraud is a growth industry, unfortunately. There's never been shortage of bad people doing bad things" (cited from Simpson, 2007, p.1).

\section{Conclusion}

Forensic accounting has been in existence since ancient times but, of late, corporate scandals have rejuvenated the profession. This study documents that forensic accounting in Malaysia is still in its infancy stage and that most Malaysians seem to assume that there is no difference between forensic accounting and auditing. From the study, it can be concluded that the slow progress of forensic accounting in Malaysia may be due to two main reasons. Firstly, forensic accounting is seen as an expensive service that only the big companies can afford. Moreover, it will also be costly if the suspected wrongdoing is brought to court, especially if it involves a forensic accountant as an expert witness. Secondly, there is no mandatory requirement for companies to conduct forensic accounting, even for companies in financial distress. Also, there is a need for a specific act or guideline to govern and regulate the forensic accounting practices in Malaysia. Another factor brought to light is the importance of the role of whistleblowers to 
expose wrongdoings within their organisations. However, the lack of protection for whistleblowers prevents people from coming forward to highlight illegal or unethical acts by companies. Most of the respondents believe that new legislation to protect whistleblowers from retaliation will help create an open environment in which individuals can raise concerns without fear of recrimination.

This study provides some useful insights for the relevant parties - regulators, researchers and academics - regarding the current development of forensic accounting in Malaysia. Given the importance and the demand for forensic accounting expertise, the weaknesses and barriers to the development of forensic accounting must be tackled by the Government. Further, there is also a need for the local universities to introduce forensic accounting programmes at the postgraduate level, since, at present, only UiTM offers such a programme.

\section{References}

Abdullah Hj. Ahmad Badawi (Datuk Seri) (2003). Keynote Address $4^{\text {th }}$ Regional Anti-Corruption Conference for Asia and the Pacific. http://www.pmo.gov. my/WebNotesApp/ PMMain.nsf /hv_ PMKoniSemasaNew/C02590E31 (assessed June 28, 2005).

American Malaysian Chamber of Commerce (AMCHAM) Update: Issue 28 (December 2003): Anti-Corruption Drive Increases Malaysia's Investment Appeal. http://www.amcham.com.my/update/28_news5.htm (assessed June 21, 2005).

Bernama.com (2004) Forensic Accounting Experts To Tackle White-Collar Crimes. http://www.bernama.com/bernama/v3/news_lite.php?id=105971 (assessed June 21, 2005).

Bolgna, J.G. and Lindquist R.J. (1987). Fraud Auditing and Forensic Accounting: New Tools and Techniques. Hoboken, New Jersey: Wiley Publishers.

Covaleski, J.M. (2003). Many top growth areas resolve around synergy of CPA/ attorney relationship. Accounting Today. March 18-7:1.

Crumbley, D.L. (2001). Forensic Accounting: Older Than You Think. Journal of Forensic Accounting. Vol. 11, pp 181 - 202.

Crumbley. D.L. and Apostolou, N. (2002). Forensic Accounting: A New Growth Area in Accounting. Ohio CPA Journal, July - September.

James A. Digabriele (2008). An Empirical Investigation of the relevant skills of forensic accountants. Journal of Education for Business, 83, 6, pp. 331-338.

Gray, Dahli (2008). Forensic Accounting and Auditing: Compared and Contrasted to Traditional Accounting and Auditing. American Journal of Business Education, vol.1, 2, pp. 115-126

Grippo, F.J. and Ibex, J.W. (2003). Introduction to Forensic Accounting. The National Public Accountant, Washington, pp 4.

Harris, C.K. and Brown, A.M. (2000). The Qualities of a Forensic Accountant. Pennsylvania CPA Journal. Vol. 71 (Spring), No. 1, pp. 6-7. 
Messmer, M. (2004). The Forensic Accountant: The Sherlock Holmes of the Accounting World. Business Credit, Vol. 106, 2, pp. 50 - 51.

Peloubet, M.E. (1946). Forensic Accounting: It's Place in Today's Economy. Journal of Accountancy, Vol. 81, No. 6, pp. 458 - 462.

Ramaswamy, V. (2005) Corporate Governance and the Forensic Accountant. The CPA Journal, New York, Vol. 75, 3, pp 68-70.

Rezaee, Z. And Burton, E. J. (1997). Forensic accounting education: insights from academicians and certified fraud examiner practitioners. Managerial Auditing Journal, 12, 9, pp. 479-489.

Spathis, C. T. (2002). Detecting false financial statements using published data: some evidence from Greece. Managerial Auditing Journal, 17, 4, pp. 179-191.

Stimpson, Jeff (2007). Forensic Accounting: Exponential Growth. Available from: http://www.webcpa.com/article.cfm?articleid=23165

Syed Noh Syed Ahmad (2003). Developing Expertise in Forensic Accounting to Help Investigate and Prosecute Bribery Available from: http://www1. oecd.org/daf/asiacom/pdf/ws3a_syedahmad.pdf (assessed June 20, 2005).

Thornhill, W.T. (1995). Forensic Accounting: How to Investigate Financial Fraud. New York: Irwin Professional Publishing.

Taylor, John (2011). Forensic Accounting. England: Pearson.

The Star, (June 24, 2006).

The Star, (November 30, 2004). 